\title{
Subject Research Overview of "Study on the Influence of the Patronage of 'South Central' Folk Kiln Guild in Ming and Qing Dynasties on Ceramic Design"
}

\author{
Fuxin Liang ${ }^{1}$ \\ Huanghe Science and Technology College \\ Zhengzhou, China, 450003 \\ e-mail: 125135189@qq.com
}

\author{
Junxia Yan ${ }^{2}$ \\ Shangqiu Institute of Technology \\ Shangqiu, China, 476000 \\ e-mail: 470265746@qq.com
}

\begin{abstract}
As an important research perspective in art history, "art patronage" has been formed and developed in recent years. Enlightened by this perspective, "Study on the Influence of the Patronage of 'South Central' Folk Kiln Guild in Ming and Qing Dynasties on Ceramic Design" introduces "patronage" into the research field of design history, and opens a new path for researching design history.
\end{abstract}

Keywords-South Central; folk kiln in Ming and Qing Dynasties; guild; patronage; ceramic design

\section{OVERVIEW OF SUBJECT RESEARCH}

Analyzed from the perspective of disciplinary research, the subject "Study on the Influence of the Patronage of 'South Central' Folk Kiln Guild in Ming and Qing Dynasties on Ceramic Design" belongs to the research field of design art history. Up to now, there were innumerable great research achievements in design art history by domestic and foreign scholars. The research object, research method and research perspective, etc. of design art history continually innovate with the development of discipline and cognition. The research on design art history also has diversified developmental directions.

\section{A. In Foreign Countries}

1) Research thought. The research on design art history first is affected by art history research where the designer is the core clue and subject material. "A Century of Design-Design Pioneers of the 20th Century" by British Penny Sparke and "Design: The 50 Most Influential Designers in the World" by Paul Rogers are typical representations.

2) Research object. For the research on modern design art history, the pioneer of British design history, Nikolaus Pevsner, adopts a "panoramic" exploration covering many fields of design--graphic design, industrial design, architectural design and interior design in his work

${ }^{1}$ Fund project: One of achievements of "The Influence of the Patronage of 'South Central' Folk Kiln Guild in Ming and Qing Dynasties on Ceramic Design" project funded by humanities and social sciences research project of The Education Department Henan Province in 2015, Project No.: (2015QN-393).
"Pioneers of Modern Design: From William Morris to Walter Gropius". The "History of Graphic Design" by American Meigs, and "History of Visual Communication and Design" written by Japanese Baishi Heye explore the topic from the angle of design--visual communication and conduct "category design history" research.

3) Research perspective. Winckelmann is the founder of German modern art history. His works "The History of Ancient Art" pioneered the combination of art and sociology, and explored the external reasons promoting the continuous change of art. From this point, Winckelmann built the "bridge" linking art history and other disciplines. In the 20th century, especially after the end of World War II, many disciplines gradually "integrated" and many interdisciplinary subjects were born, thereby promoting further improvement of disciplinary study and of people's cognition. In 1967, "Popular System--Semeiology and Clothes Codes" by French semiotician Roland Barthes was published, opening a new road for the exploration of design history from the perspective of semiotics. "The Language of Post-modern Architecture" by Charles Jencks in 1977 was affected by this emerging practice. When American design theorist Victor Papanek's controversial "Design for the Real World" was published in 1971, the perspective of studying the development of design history through the lens of ethnicity emerged.

\section{B. In China}

Before the concept of modern design had a deep influence on China, the exploration of the history of arts and craftsmanship by many scholars can be regarded as the "rudiment" of early design study in China. Meanwhile, we shall point out that many scholars' integration and cognition process for "design of arts \& crafts" runs parallel. The research system used for the history of arts and crafts still has a deep influence on domestic scholars studying design art history today. In 1985, "History of Chinese Arts and Crafts" of Mr. Tian Zibing was published. Its influence 
remains strong to this day. His "Venue Decoration" written in early 1952 can be regarded as the illustration of the modern design idea.

The influence of Mr. Tian Zibing's research system can be seen in relevant research results throughout the history of arts and crafts and in the works of many domestic scholars-such as "History of Chinese Arts and Crafts" by Xu Simin, "History of Foreign Art and Design" by Zhang Fuye and "Study on Yuan Dynasty Arts and Crafts" by Shang Gang who researched dynastic history.

Mr. Pang Xunqin, who is the pioneer in promoting the development of the Chinese modern design concept, published "Study on Pattern Issues" in 1953. This works can be regarded as one of the earliest theoretical works exploring graphic design in China. With the advancement of reform and opening-up policy, the concept of modern design has been gradually introduced and studied by many domestic scholars, thereby promoting the unprecedented flourishing of Chinese design art history research, and the publication of many books such as "History of Ancient China Design Art" and "History of Modern Design Art".

"From Pattern to Design: Study on History of 20 Century Chinese Design Art" explores the development and evolution of the "western design concept" in modern day China. Mr. Zhang Daoyi has always explored the dialectical relationship between "Arts \& crafts and design, modernity and tradition, internationalization and nationality", and devoted himself to promoting the contemporary development of design nationalization. Scholars such as Hang Jian and Li Yanzu explore how design in contemporary China can be nationalized and how it can serve the public and social economy. Works such as the collected papers "Home · Design" by Hang Jianand "Design Research: Design for National Identity and People's Livelihood" edited by Li Yanzu reflect the above-mentioned sentiment.

In addition, in study of design art history, China also has witnessed the diversified development of research perspectives. In 2004, Li Lixin published "The Research of China Art Design History". His research perspective of design art history is turned from traditional "implements" to "craftsman", and deeply explores the fundamental power and essential rules promoting the continuous evolution of Chinese design art.

The research perspective of this subject is greatly affected by Mr. Li Lixin. The authors turn the research object of design history from "studying the arts and crafts features of ceramic" to the "main body of ceramic design--craftsman, namely, kilnman". In exploring the factors promoting the continuous evolution of folk kilns' ceramic design and production, the authors select "guild patronage" as a primary factor, which was of no concern to most scholars in the field of design history.

"Patronage" is a term borrowed from economics and sociology. The history of western art school includes it in the study of design, thereby forming the concept of "art patronage". Today, this perspective has become the hotspot of academic research on Chinese and foreign art history. The research perspective and research method, etc. of this subject are greatly enlightened by art patronage. Many western works such as "Sponsor and Painter" by Haskell, "Rethinking the Renaissance--Burgundian Arts across Europe" by American Marina Belozerskaya, "The Italian Renaissance: Culture and Society in Italy" by Peter Berck and "The Painters Practice: How Artists Lived and Worked in Traditional China" by American James Cahill explored the complex relationship between sponsor, artist and art creation, highlighting the influence of "patronage" on the history of art development. In China, works such as "Market and Style Change of Modern Painting and Calligraphy with Shanghai as Center (1843-1948)" by Chen Yongyi and "Appraisal and Management: Study on Art Patronage of Huizhou Merchants in Late Ming and Early Qing Dynasties" by Zhang Changhong also regard "art patronage" as a core research object. A large number of studies on art patronage by many domestic and overseas scholars provide useful references for researching this subject.

\section{PRACTICAL SignifiCANCE AND THEORETICAL SIGNIFICANCE OF THIS SUBJECT RESEARCH}

Based on the aforementioned discussion, the authors believe that the practical significance and theoretical significance of this subject research mainly include the following aspects:

1. Expand the research method and research perspective of design art history and explore the unique dynamic factor promoting the development of design history, thereby further perfecting the research system of design history.

2. Traditional ceramic design is very complex, consisting of the design method, its organization, design operation mode, etc. The study on these contents aims at proving that "South Central" traditional ceramics industry contains the core factor that promotes the transformation to modern design and industrialization. Meanwhile, it also provides a useful reference for aspects such as the organizational pattern of modern design groups and the organization and management of the designer.

3. The core question of this subject material is: under the influence of "guild patronage", what important aspects emerged in relation to the inheritance of porcelain craft making, the learning of design method, the formation of design artistic style and mode of craftsman organization in "South Central" folk kiln during the Ming and Qing Dynasty, and, using that reference, what changes can be revealed in the modern design industry and modern educational system?

The contemporary Central China is undergoing a comprehensive change with the construction of a new economic cultural area. Design education is a primary strength in the education of cultural industry talents and the key link promoting the Central Plain's Culture march toward nationalization, modernization and global concentration. Therefore, all sectors of society shall pay special attention to it. The innovation of design history research does more than perfect the construction of a design system. Meanwhile, by facing the past, we can dig up the essence and successful experiences of traditional design, thereby providing a 
reasonable theoretical guide to promoting the current design culture industry of the Central Plains economic region, which continuously conforms to the needs of nationality, modern times, and national development.

\section{MAIN CONTENTS OF THIS SUBJECT RESEARCH}

According to the research needed, the main contents of this subject's research include the following aspects:

1. The realistic overview of fields such as social economy, humanistic thought and artistic aesthetics in the Ming and Qing Dynasties, which is basically clarified with the following; the overall social and economic conditions of "South Central" in this period are specially focused, thereby laying the foundation for further study.

2. The craft, type and regional landscape of "South Central" ceramic in the Ming and Qing Dynasties, as well as the difference between folk kiln and official kiln, are briefly explored. Meanwhile, the production, sales and the export sales conditions of folk kiln are discussed. Henan folk kiln, Jiangxi Jingdezhen folk kiln and Guangdong export folk kiln are specially studied.

3. The organizational method, institutional norm, belief \& worship, formation objective of various ancient handicraft industry "guilds", as well as their influence on industry and member development are intensively studied. The authors specially focus on and intensively study the influence of various measures adopted by guilds in the ceramic industry on the inheritance and innovation of ceramic arts and crafts, interest of craftsman and sales of ceramic products, etc. The research of this content lays a theoretical basis for exploring the influence of guild patronage on ceramic design.

4. According to the needs of this subject research, the authors pay special attention to the following folk kilns located in "South Central" in the period of Ming and Qing Dynasty: Jun kiln; Quyang kiln; Qinghua kiln; Jingdezhen folk kiln; Boluo, Jieyang and Chengmai export folk kiln; Shiwan kiln; Jiangxia Husi kiln; Changsha kiln (Tongguan kiln). In addition to the above-mentioned kiln sites, if necessary, the author will also extend the research scope to include kiln sites in order to guarantee the adherence to scientific principles and rational argument.

5. In addition to conducting the above-mentioned detailed studies on porcelain making and on the product features of folk kiln located in "South Central" during the Ming and Qing Dynasties, this subject will also delve into the following aspects: Organizational form, personnel composition, customs \& beliefs, institutional norms (such as system of rewards and penalties, membership systems, welfare systems, assistance \& subsidization, craft inheritance and stipulations for the master-apprentice relationship), etc. Classification of "South Central" folk kiln guilds: pottery guilds, kilnman guilds and ceramic merchant guilds, and the relationship of these three guilds; Specific meaning of "guild patronage" in this subject; important content of "patronage" of folk kiln located in "South Central" in the Ming and Qing Dynasties, to which careful attention is paid to the organization of "South Central" export guilds and its patronage form.

6. According to the research of relevant subjects during the early stages, the authors deduce that important functions of guild patronage in regards to this subject include the guild: 1) providing the tools and a production place for ceramic design; providing various support to public activities organized by folk kiln guild such as worship, celebration and competition, for example a fund, personnel and a site; 2) promoting the communication and spread of ceramic production craft and technology; easing the heavy taxes levied by the government on potter and kilnman by mediating between the two, thereby maintaining the interest of guild members to a certain degree; 3) taking advantage of obtained regional advantage, the guild will further reduce the competition within the ceramic industry in the same region, and create a more stable market share for each member; 4) playing the role of credit guaranty between the manager of kiln and peddlery, avoiding the adverse effects of capital shortage of one party on the whole circulation chain of ceramic, including design, production and sales; 5) Guarantee folk kiln's exclusivity on its ceramic product "trademark (inscription)", further maintaining the economic interest of guild member; 6) finally, with the continual growth of ceramic export trade, the guild play an increasingly important role. The authors will also pay special attention to this point in the research process.

7. Under the premise of completing main contents of guild patronage, the authors will further deeply analyze the role and influence of guild patronage on ceramic design activity. Firstly, they will establish the meaning of "design" in this subject; Secondly, they will deeply analyze the complex relationship between the two. According to the above-mentioned research content on guild patronage, the authors believe that the influence of guild patronage on ceramic design can be divided into direct influence and indirect influence.

8. Generally speaking, the influence of guild patronage on "ceramic design" mainly includes: 1) promoting the communication and learning of ceramic technology within guild and among regions; 2) stabilizing the master and apprentice relationship, and maintaining the inheritance of ceramic technology; 3) providing the opportunity of leisure and entertainment for members, and improving the production efficiency of ceramics; 4) building a good social image of the guild and promoting the sale of ceramic products; 5) guaranteeing the basic interests of members, and improving the craftsman's enthusiasm to carry out ceramic design and production; 6) safeguarding the members beliefs, stabilizing and promoting the design, production and trade of ceramic; 7) harmonizing the benefit distribution relationship within guild members and between the government, and forming a regional advantage to promote the sale of ceramic products; 8) forming the "brand" advantage of ceramic product, and promote the mass and standardized design and production method of ceramic products; 9) coordinating the relationship among potter guilds, kilnman guilds and ceramic merchant guilds to promote the development of the ceramics industry; 10) Influence in other aspects. 
Substantially, there are advantages and disadvantages with the influence of guild patronage on ceramic design. We shall select the advantages and use them to provide assistance for scientific and reasonable development of a contemporary design education pattern and designer organizational form.

\section{Basic Thought And Method of SubJect RESEARCH}

From the main contents and viewpoints of the abovementioned subject research, we can draw that the research thought of this subject can be generalized as a study from the whole to the local, from a group to the individual, and from ancient times to the present. The specific research thought is shown in the following chart.

According to actual demands of subject research, the method and technological means of this subject research include "Table I":

1. Data collection; searching for historical data related to subject research especially guild patronage.
2. Ancient literature sorting: this is an important means directly exploring the real situation of folk kiln production in "South Central" during the Ming and Qing Dynasties;

3. Economic history and social history--especially content from social history related to various methods, perspectives and theories of guild research;

4. Field investigation: conduct field investigations for folk kiln sites, and study the craft and organization structure, etc. of traditional ceramic production.

5. Technology. The design and production of ancient ceramics are completed by manual operation. Many complex crafts and production processes, such as raw material production, molding, fettling, decoration, and the encastage and burning of ceramic, can be accurately understood and mastered with the knowledge of technology.

6. In addition, the authors also use the methods of system, analysis and comparison in the writing process of subject.

TABLE I. CHART FOR BASIC THOUGHT OF SUBJECT RESEARCH

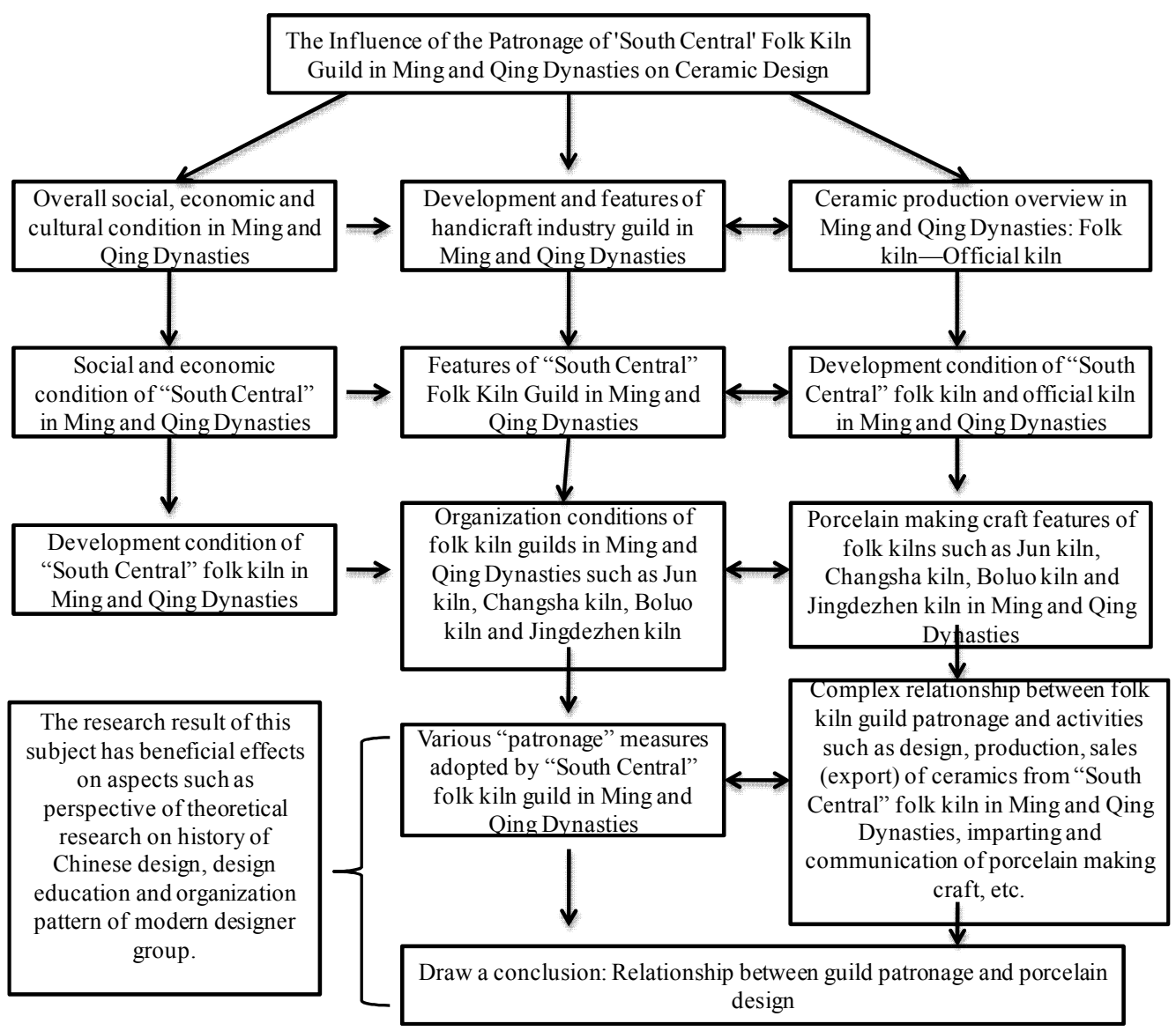




\section{CONCLUSION}

This subject, "Study on the Influence of the Patronage of 'South Central' Folk Kiln Guild in the Ming and Qing Dynasties on Ceramic Design", is the in-depth study and expansion of the following two research subjects, "The influence of guild patronage on porcelain design of Cizhou kiln in the Song dynasty" (Graduation thesis of master degree candidate from Wuhan University of Technology in 2012) and "The influence of patronage of guild on Central Plains porcelain design during the Ming and Qing Dynasties" (The youth humanities and social sciences research project approved by The Education Department Henan Province in 2013 and completed in 2014). The authors will search and sort out many historical facts to explore the complex relationship between guild patronage and porcelain design.

\section{REFERENCES}

[1] Zhang Changhong. Appraisal and Management: Study on Art Patronage of Huizhou Merchants in Late Ming and Early Qing Dynasties [M]. Beijing: Peking University Press, 2010

[2] Written by Marina Belozerskaya (American), Rethinking the Renaissance--Burgundian Arts across Europe [M]. Translated by Liu Xinyi. Jinan: Shandong Pictorial Press, 2006.

[3] Chinese Ceramic Society. History of Chinese Ceramic [M]. Beijing: Cultural Relics Publishing House, 1982

[4] Quan Hansheng. History of Chinese Guild System [M]. Taipei: Shihuo Press Co., Ltd., 1986

[5] Li Lixin. The Research of China Art Design Histroy[M]. Beijing: People's Publishing House, 2011 